\title{
OVERVIEW OF THE MARKET ABUSE REGULATION UNDER THE FINANCIAL MARKETS ACT 19 OF 2012
}

\author{
Howard Chitimira* \\ LLB LLM LLD \\ Lecturer, Faculty of Law \\ North West University \\ Mafikeng
}

SUMMARY

This paper analyses the regulation of market abuse under the Financial Markets Act 19 of 2012 in order to investigate the adequacy of such regulation as regards to the combating of market-abuse practices in South Africa. To this end, the paper provides an overview analysis of the market abuse (insider trading and market manipulation) offences as well as the penalties and other anti-market abuse-enforcement approaches that are employed under the Financial Markets Act 19 of 2012 in a bid to provide a revamped and adequate anti-market abuse regulatory and -enforcement framework in South Africa. Moreover, where possible, the paper also provides a comparative analysis of these offences, penalties and other anti-market abuseenforcement approaches and those that were provided under the Securities Services Act 36 of 2004. This is done to examine whether the anti-market abuse regulatory and -enforcement framework that was re-introduced under the Financial Markets Act 19 of 2012 has now adequately resolved the flaws and gaps that were associated with a similar framework under the former Act.

\section{INTRODUCTION}

It is submitted that there is no comprehensive and satisfactory definition of "market abuse" that exists to date. ${ }^{1}$ However, for the purposes of this article "market abuse" is used as a generic term referring to insider trading and market manipulation. ${ }^{2}$ South Africa had anti-market abuse legislation in place since the late 1990s but nonetheless the enforcement of such legislation to combat market-abuse activities has been inconsistent and

I wish to acknowledge the expert mentoring and unwavering support of Professor Lawack. See further Fischel and Ross "Should the Law Prohibit 'Market Manipulation' in Financial Markets" 1991 Harvard LR 503 506; and Avgouleas The Mechanics and Regulation of Market Abuse: A Legal and Economic Analysis (2005) 104.

2 These practices are outlawed in South Africa and several other countries globally in a bid to, inter alia, avoid their potentially negative effects such as low investor confidence and poor market integrity. 
problematic to date. ${ }^{3}$ Accordingly, the effects of market abuse have been felt in a number of financial markets globally. ${ }^{4}$ South Africa is not an exception. ${ }^{5}$ A reputation of high levels of market-abuse practices associated with the South African financial markets in the mid 1990 s is a case in point. ${ }^{6}$ In an attempt to effectively combat market abuse in the South African financial markets, the Securities Services $\mathrm{Act}^{7}$ was enacted to repeal all the flawed provisions of the Insider Trading Act $^{8}$ and improve the enforcement of the market-abuse prohibition in South Africa. Moreover, the Securities Services Act was recently repealed by the Financial Markets Act in another attempt to, inter alia, improve the curbing of market-abuse activities in the South African financial markets. It is against this background that this article analyses the regulation of market abuse under the Financial Markets Act in order to investigate the adequacy of such regulation as regards to the combating of market-abuse practices in South Africa. To this end, the article provides an overview analysis of the market-abuse offences as well as the penalties and other anti-market abuse-enforcement approaches that have been employed in the Financial Markets Act in a bid to provide a revamped and adequate anti-market abuse regulatory and -enforcement framework in South Africa. Moreover, where possible, the article also provides a comparative analysis of the offences, penalties and other anti-market abuse-

3 Jooste "A Critique of the Insider Trading Provisions of the 2004 Securities Services Act" 2006 SALJ 437 441-460; Osode "The New South African Insider Trading Act: Sound Law Reform or Legislative Overkill?" 2000 Journal of African Law 239 239; Van Deventer "New Watchdog for Insider Trading" 1999 FSB Bulletin 2 3; the King Task Group into Insider Trading Legislation Minority Report on Insider Trading 1997 par 3.4 as summarized in Beuthin and Luiz Beuthin's Basic Company Law (2000) 235-238; also see generally Chitimira The Regulation of Insider Trading in South Africa: A Roadmap for an Effective, Competitive and Adequate Regulatory Statutory Framework (2008) LLM-dissertation, University of Fort Hare, 41-72.

4 Myburgh and Davis "The Impact of South Africa's Insider Trading Regime: A Report for the Financial Services Board" (25-03-2004) 8 http://www.genesis-analytics.com/public/FSB Report.pdf (accessed 2013-02-09); generally see Bhattacharya and Daouk "The World Price of Insider Trading" http://www.faculty.fuqua.duke.edu/ charvey/Teaching/BA453 2004/BD_Theworld.pdf (accessed 2013-06-19); and Van Deventer "Anti-Market Abuse Legislation in South Africa" (10-06-2008) 1-5 http://www.fsb.co.za/public/marketabuse/ FSBReport.pdf (accessed 2013-05-05).

5 Van Deventer (10-06-2008) 1-4 http://www.fsb.co.za/public/marketabuse/FSBReport.pdf (accessed 2013-05-05); also see further Myburgh and Davis (25-03-2004) 8-13 http://www. genesis-analytics.com/public/FSBReport.pdf (accessed 2013-02-09).

6 Myburgh and Davis (25-03-2004) $11<$ http://www.genesis-analytics.com/public/FSBReport. pdf (accessed 2013-02-09). Notwithstanding the fact that this Myburgh and Davis report was published in 2004 before the Securities Services Act came into effect and the fact that it was somewhat influenced by the opinions of the interviewees, it shall be referred to in this article where necessary, not as the only basis or evidence of the existence of market-abuse activity in the South African financial markets but as a pointer on how market-abuse laws were enforced in South Africa prior to the enactment of the Securities Services Act. Moreover, the Myburgh and Davis report and a few other selected and available reports and/or sources will be referred to throughout this note because there are currently very few new sources on the regulation and enforcement of the market-abuse prohibition in South Africa, especially under the Financial Markets Act.

736 of 2004 (hereinafter "the Securities Services Act") and it came into effect on 1 February 2005. The Securities Services Act has now been repealed and will only be referred to where necessary for historical comparative purposes since there are currently very few sources on the regulation of market abuse under the Financial Markets Act 19 of 2012, hereinafter referred to as the Financial Markets Act and it came into effect on 03 June 2013.

8135 of 1998 (hereinafter "the Insider Trading Act"). 
enforcement approaches that are employed in the Financial Markets Act and those that were provided under the Securities Services Act. This is done to examine whether the anti-market abuse regulatory and -enforcement framework that was reintroduced under the Financial Markets Act has now adequately resolved the flaws and gaps that were associated with a similar framework under the former Act. This is further done to examine whether the Financial Markets Act's market-abuse prohibition is being properly enforced. ${ }^{9}$ This is also aimed at increasing awareness on the part of the relevant stakeholders. In relation to this, the article discusses other additional measures that can, where necessary, be incorporated into the Financial Markets Act's market-abuse prohibition to improve its enforcement. ${ }^{10}$ Notably, three forms of market abuse, namely insider trading, prohibited trading practices (trade-based market manipulation) and the publication of false, misleading or deceptive statements relating to listed companies (disclosure-based market manipulation), are prohibited in South Africa. ${ }^{11}$ However, notwithstanding the anti-market abuse efforts introduced by the Financial Markets Act, more may still need to be done to increase the number of convictions and settlements in cases involving market abuse in South Africa. ${ }^{12}$

\section{THE REGULATION OF MARKET ABUSE UNDER THE FINANCIAL MARKETS ACT 19 OF 2012}

\section{Definitions of selected terms and concepts}

\section{The concept of market abuse}

"Market abuse" is not expressly defined in the Financial Markets Act. However, a number of practices that could give rise to criminal and civil liability for market abuse are merely stated in the Financial Markets Act. ${ }^{13}$ For instance, three forms of market abuse, namely insider trading, tradebased market manipulation and disclosure-based market manipulation relating to listed securities are prohibited under the Financial Markets Act. This status quo was directly borrowed from the Securities Services Act ${ }^{14}$ without any useful changes and/or definitions of the concepts of insider trading, market manipulation or market abuse.

9 See sub-paragraphs under paragraphs 21 and 22 below.

10 In spite of the paucity of convictions and settlements in civil and criminal cases involving market abuse, the legislature has relatively managed to improve and raise the South African financial markets up to a level that would make them more comparable to the highest standards of similar markets in the developed world and international best practice by enacting some definitions as well as civil and administrative sanctions against market abuse.

11 See s 78, s 80, s 81 and s 82 of the Financial Markets Act. Notably, the same market-abuse offences were also outlawed in s 73, s 75, s 76 and s 77 of the Securities Services Act. This suggests that no new types of market-abuse offences such as attempted insider trading and attempted market manipulation were introduced under the Financial Markets Act.

12 Ibid.

13 See s 78 , s 80 , s 81 and s 82.

14 See s 73, s 75, s 76 and s 77. 
Insider trading is specifically prohibited in the Financial Markets Act. ${ }^{15}$ For example, any person who knew that he had non-public price-sensitive information and who disclosed it improperly or encouraged or discouraged another person from dealing, or who dealt directly or indirectly for his own benefit or for the benefit of any other person in securities to which such information relates, or where the price of such securities was likely to be affected by such dealing will incur criminal or civil liability for insider trading. ${ }^{16}$ The same practices were also outlawed in the Securities Services Act ${ }^{17}$ and later re-introduced in the Financial Markets Act, ${ }^{18}$ without providing any new insider trading-related offences such as an "attempted insider-trading offence" and/or a specific "tipping" offence.

Trade-based market manipulation is further prohibited in the Financial Markets Act. ${ }^{19}$ Examples of activities that are deemed to be manipulative include executing a transaction with no beneficial change of ownership of the securities, and entering orders into the market near the close of the market, or during the auctioning process for the purpose of creating a deceptive appearance in that market. ${ }^{20}$ The same approach was employed in the Securities Services $\mathrm{Act}^{21}$ and accordingly, similar conduct that amounts to, or that may be deemed to constitute trade-based market manipulation, is also outlawed in the Financial Markets Act. ${ }^{22}$

Disclosure-based market manipulation is also prohibited in the Financial Markets Act. ${ }^{23}$ This prohibition on the making or publication of false, misleading or deceptive statements, promises and forecasts can be welcomed because such information often distorts the market price of securities, giving rise to direct or indirect prejudice to innocent market participants. The same practices were recycled from and/or prohibited in the Securities Services Act, ${ }^{24}$ but nonetheless Internet-related manipulative disclosures are still not expressly outlawed in the Financial Markets Act. ${ }^{25}$

Notwithstanding the fact that the Financial Markets Act was enacted as a separate piece of legislation that consolidated all previous market-abuse provisions of the Securities Services Act, the regulation and enforcement of the market-abuse ban in South Africa have remained scant and inconsistent to date. ${ }^{26}$ This could have been, inter alia, aggravated by the fact that it would only amount to market abuse if the accused person knew that he contravened, directly or indirectly, the relevant provisions of the Financial Markets Act. This suggests that the knowledge of the market-abuse offence

See $\mathrm{s} 78$ and $\mathrm{s} 82$.

See $\mathrm{s} 78$ and $\mathrm{s} 82$ respectively.

See $\mathrm{s} 73$ and $\mathrm{s} 77$.

See $\mathrm{s} 78$ and 82 .

S 80.

A brief discussion on each of the sub-sections under $\mathrm{s} 80$ will be carried out later.

S 75.

S 80.

S 81.

S 76.

S 81.

Van Deventer (10-06-2008) 1-4 http://www.fsb.co.za/public/marketabuse/FSBReport.pdf (accessed 2013-05-05). 
in question is required on the part of the offenders before any liability can be imputed on them. Nonetheless, the Financial Markets Act, like the Securities Services Act, ${ }^{27}$ does not provide any presumptions which could be used to enhance the prosecution of market-abuse cases in South Africa. ${ }^{28}$ It is suggested that enacting a statutory provision for a definition of the concept of "market abuse" involving all the elements of this offence (how it is committed), many types of market abuse and presumptions could improve the enforcement of the market-abuse prohibition in South Africa. Moreover, notwithstanding the difficulties that might have been encountered in relation to factors like repetition of same provisions, double jeopardy and overcriminalization of market-abuse practices in different statutes, the mere consolidation of the market-abuse provisions into the Securities Services Act and recently, in the Financial Markets Act on its own did not sufficiently improve the enforcement of the market-abuse ban in South Africa. ${ }^{29}$ Given the fact that the Financial Market Act's market-abuse provisions duplicated some of the flaws contained in the Securities Services Act, it remains to be seen whether the Financial Markets Act's market-abuse prohibition will enhance the combating of market abuse in South Africa.

\section{The meaning of "market corner" and "market-abuse Rules"}

"Market corner" is defined as any arrangement, agreement, commitment or understanding involving the purchasing, selling or issuing of securities listed on a regulated market by which a person, or a group of persons acting in concert, acquires direct or indirect beneficial ownership of, or exercises control over, or is able to influence the price of securities listed on a regulated market; and where the effect of the arrangement, agreement, commitment or understanding is or is likely to be that the trading price of the securities listed on a regulated market, as reflected through the facilities of a regulated market, is or is likely to be abnormally influenced or arbitrarily dictated by such person or group of persons in that the said trading price deviates or is likely to deviate materially from the trading price which would otherwise likely have been reflected through the facilities of the regulated market on which the particular securities are traded. ${ }^{30}$ This definition discourages market manipulation through the creation of a false impression of the volumes traded in securities or abnormal and artificial trading prices in listed securities. Even so, a "market corner" could only be formed after an arrangement or agreement in respect of the selling, issuing or purchasing of securities listed on a regulated market was made by a person or the persons involved. Instances where a "market corner" could have been formed in respect of, and/or influenced by securities traded in the over-the-counter markets are not expressly outlawed in the Financial Markets Act. This flaw

\footnotetext{
See s 73, s 75, s 76 and s 77 .

28 See s 78, s 80, s 81 and s 82 of the Financial Markets Act.

29 Van Deventer (10-06-2008) 1-4 http://www.fsb.co.za/public/marketabuse/FSBReport.pdf (accessed 2013-05-05).

30 S 77 of the Financial Markets Act. The same definition was recycled from s 72 of the Securities Services Act without providing any changes.
} 
was borrowed from the Securities Services $\mathrm{Act}^{31}$ and has remained unresolved under the Financial Markets Act. ${ }^{32}$

"Market-abuse rules" is defined to include the duties of the Financial Services Board to make relevant rules concerning the administration of market abuse by the Financial Services Board and the Directorate of Market Abuse; the manner in which investigations of market abuse are to be conducted; the notification of any civil monetary compensatory amounts received; the procedure for the lodging and proof of claims; the administration of trust accounts and the distribution of payments in respect of claims; the meetings of the Directorate of Market Abuse which are generally designed to ensure that the Financial Services Board and the Directorate of Market Abuse are able to perform their functions dealing with the manner in which inside information should be disclosed, and with the conduct expected of persons with regard to such information. ${ }^{33}$ The Financial Services Board has discretion to make such "market-abuse rules" only after consulting with the Directorate of Market Abuse. Besides this, no express provision is made in the Financial Markets Act to empower the Financial Services Board to make its own market-abuse rules pertaining to the enforcement of criminal and administrative sanctions for market-abuse offences. This flaw was borrowed from the Securities Services Act ${ }^{34}$ and reintroduced in the Financial Markets $\mathrm{Act}^{35}$ without providing any alternative ways that could empower the Financial Services Board to make its own market-abuse rules pertaining to the enforcement of criminal and administrative sanctions for market abuse.

\section{The meaning of "person" and "regulated market"}

The term "person" is defined to include a partnership and any trust. ${ }^{36}$ This implies that market-abuse offences could be committed by an insider or a "person" as defined who misuses inside information and not by "individuals" alone. Accordingly, an "insider" means a person who has inside information through being a director, employee or shareholder of an issuer of securities listed on a regulated market to which the inside information relates, ${ }^{37}$ or having access to such information by virtue of employment, office or profession, ${ }^{38}$ or where such person knows that the direct or indirect source of the information was an insider as contemplated in the Financial Markets Act. $^{39}$ "Inside information" means specific or precise information which has

\footnotetext{
See $\mathrm{s} 72$.

S 77.

$\mathrm{S} 84(2)(\mathrm{f})(\mathrm{i})$ to $(\mathrm{vi})$ of the Financial Markets Act.

$\mathrm{S} 82(2)(\mathrm{g})(\mathrm{i})$ to $(\mathrm{vi})$.

$\mathrm{S} 84(2)(\mathrm{f})(\mathrm{i})$ to $(\mathrm{vi})$.

S 77 of the Financial Markets Act. The same definition was copied from s 72 of the Securities Services Act.

37 S 77(a)(i) of the Financial Markets Act. The same definition was recycled from s 72(a)(i) of the Securities Services Act.

38 S 77(a)(ii) of the Financial Markets Act. The same definition was recycled from s 72(a)(ii) of the Securities Services Act.

$39 \mathrm{~S} 77$ (b) of the Financial Markets Act. The same status quo was recycled from s 72(b) of the Securities Services Act.
} 
not been made public and which is obtained or learned by an insider and which, if it were made public, would be likely to have a material affect on the price or value of any security listed on a regulated market. ${ }^{40}$ However, Jooste argues that the definition of "person" leaves some doubt as to whether it also includes a corporate ${ }^{41}$ or any other legal entity. ${ }^{42}$ The author agrees in part with Jooste, and submits that the confusion is caused by the employment of the phrases "he or she" in some market-abuse provisions of the Financial Markets Act. ${ }^{43}$ This employment of the phrases "he or she" could imply that the definition of "person" is still limited to natural persons alone. This flaw was recycled from the Securities Services $\mathrm{Act}^{44}$ and has remained unresolved in the Financial Markets Act. ${ }^{45}$

"Regulated market" means any market, whether domestic or foreign, which is regulated in terms of the laws of the country in which the market conducts business as a market for dealing in securities listed on that market. ${ }^{46}$ This suggests that market-abuse provisions had extra-territorial application. For example, any person who commits market abuse on a regulated foreign market say, by manipulating share prices or dealing on the basis of non public price-sensitive information relating to securities listed on such market while domiciled in South Africa, could be prosecuted in South Africa. ${ }^{47}$ The application of the market-abuse prohibition in the Financial Markets Act is surprisingly not limited to situations where there is a territorial link between the actual commission of market-abuse offences and South Africa. This status quo was recycled from the Securities Services Act. ${ }^{48}$ Thus, even though this extra-territorial application appears to be a sound move for curbing cross-border market-abuse activities, it has not been used more regularly, probably due to lack of adequate resources. ${ }^{49}$ From a comparative perspective, one can argue that a restricted and more practical approach should have been adopted to combat market abuse meritoriously in South Africa. ${ }^{50}$ Moreover, the market-abuse prohibition should apply to transactions on foreign markets where a territorial link is present by virtue

40 S 77 of the Financial Markets Act. The same definition was copied from s 72 of the Securities Services Act.

41 S 332(1) of the Criminal Procedure Act 51 of 1977 in this regard.

42 See the definition of "person" in s 2 of the Interpretation Act 33 of 1957. Also see Jooste 2006 SALJ 438

43 See s 78 read with s 80 and s 82.

44 See $\mathrm{s} 73$ and $\mathrm{s} 77$.

45 See $s 78$ read with s 80 and s 82 of the Financial Markets Act.

$46 \mathrm{~S} 77$ of the Financial Markets Act.

47 Jooste 2006 SALJ 453.

$48 \mathrm{~S} 72$.

49 Loubser "Insider Trading and Other Market Abuses (Including the Effective Management of Price-sensitive Information)" 2 October 2006 Insider Trading Booklet final draft 26-27 http://www.jse.co.za/public/insider/JSEbooklet.pdf (accessed 2013-10-06). Notwithstanding the fact that this Loubser report was published in 2006, it shall be referred to in this article where necessary, not as the only basis or evidence of the existence of market-abuse activity in the South African financial markets but as a pointer on how market-abuse activities are detected and discouraged in South Africa. Moreover, the Loubser report and a few other selected and available reports and/or sources will be referred to throughout this note because there are currently very few new sources on the regulation and enforcement of the market-abuse prohibition in South Africa, especially under the Financial Markets Act.

50 Jooste 2006 SALJ 453. 
either of the fact that the offender is at the time physically present in South Africa, or was acting through an intermediary who is in South Africa or by virtue of the prohibited conduct occurring in South Africa. ${ }^{51}$

Nonetheless, the timeous enforcement and recognition of foreign judgments in cross-border market-abuse cases is another challenge that could be associated with the extra-territorial application of market-abuse provisions in South Africa. Consequently, it is submitted that the South African courts should recognize, where necessary, the relevant international law and foreign law as enshrined in the Constitution. ${ }^{52}$ Apparently, if a South African citizen who is an insider but is domiciled in New York, contacted a broker in South Africa to purchase any security listed on the Johannesburg Stock Exchange Limited ${ }^{53}$ in order to conceal the illegal nature of such dealing, the Financial Services Board and/or the relevant court can cooperatively rely on the United States Securities and Exchange Commission to investigate and prosecute such person for market abuse. Moreover, when a judgment relating to such market abuse is handed down in South Africa, it will have extra-territorial force in the United States of America.

\section{Prohibited trading practices and penalties}

\section{Prohibition on "trade-based market manipulation"}

A number of trade-related manipulative practices are prohibited in the Financial Markets Act. ${ }^{54}$ For example, any person who directly or indirectly used or knowingly participated in the use of any manipulative, improper, false or deceptive practice of trading in a security listed on a regulated market, either for such person's own account or on behalf of another person, where such practice creates or might create a false or deceptive appearance of the trading activity in connection with or an artificial price for that security will be guilty of an offence. ${ }^{55}$ Additionally, any person who places an order to buy or sell listed securities which, to his knowledge could, if executed, have the effect of creating a false or deceptive appearance of the trading activity in connection with or an artificial price for such securities will be guilty of an offence. ${ }^{56}$ Other examples of trading practices that are deemed to be manipulative include, among others, executing a transaction with no beneficial change of ownership of the securities; ${ }^{57}$ entering an order to buy

51 Cassim "Some Aspects of Insider Trading - Has the Securities Services Act 36 of 2004 Gone too Far?" 2007 SA Merc LJ 4467.

$52 \mathrm{~S} 39(1)(\mathrm{b})$ and $(\mathrm{c})$ of the constitution.

53 Hereinafter "the JSE".

$54 \mathrm{~S} 80$.

55 S $80(1)(a)(i)$ and (ii) of the Financial Markets Act. The same (i) was inherited from $s$ $75(1)$ (a)(i) and (ii) of the Securities Services Act.

$56 \mathrm{~S} 80(1)(\mathrm{b})$ and (2) of the Financial Markets Act. This status quo was inherited from $s$ $75(1)(b)$ and (2) of the Securities Services Act without providing any new trade-related manipulative practices.

57 This practice is sometimes called a "wash trade". See s $80(3)$ (a) of the Financial Markets Act which inherited the provisions of $s 75(3)(a)$ of the Securities Services Act without providing any new trade-related manipulative practices. See further Alcock "Market Abuse" 2002 The Company Lawyer 142143. 
or sell a security on a regulated market knowing of a similar opposite order that has been entered, or will be entered, ${ }^{58}$ with the intention of creating a deceptive appearance of active public trading in connection with or an artificial market price for that security; ${ }^{59}$ entering on a regulated market, orders to buy or sell a security listed on that market at successfully higher or lower prices for the purpose of improperly influencing the market price for that security; ${ }^{60}$ entering on a regulated market an order at or near the close of the market to change or maintain the closing price of a security listed on that market; ${ }^{61}$ entering on a regulated market an order to buy or sell a security listed on that market during any auctioning process or pre-opening session and cancelling such order immediately prior to the opening of the market to create a deceptive or false appearance of demand for or supply for that security; ${ }^{62}$ maintaining an artificial price for dealing in securities listed on a regulated market; ${ }^{63}$ employing any device, scheme or artifice to defraud other persons as a result of a transaction effected through the facilities of a regulated market; ${ }^{64}$ engaging in an act, practice or course of business in respect of dealings in any listed securities which is deceptive or which is likely to have such effect ${ }^{65}$ and effecting a market corner. ${ }^{66}$

The offender is required to know that he was taking part in a prohibited trading practice on a regulated market and the effect or possible effect of such practice before he could incur any liability. ${ }^{67}$ This may imply that persons who engage in trade-based market manipulative practices in respect of any listed securities in South Africa could evade their liability if they prove that they ignorantly dealt in the affected securities. ${ }^{68}$ Moreover, the prohibition on trade-based market manipulation is generally limited to transactions relating to securities listed on a regulated market. ${ }^{69}$ Trade-

58 See $s$ 80(3)(b) of the Financial Markets Act which recycled the provisions of $s 75(3)(b)$ of the Securities Services Act.

59 The false trading practice need only create the false appearance of trading or artificial price and it need not actually have had the defined effect. See Luiz "Market Abuse II - Prohibited Trading Practices and Enforcement" 2002 Juta's Business Law 180180 for related comments.

60 See s $80(3)(c)$ of the Financial Markets Act which merely resembles s $75(3)(c)$ of the Securities Services Act.

61 See $s 80(3)(d)$ of the Financial Markets Act which merely resembles $s 75(3)(d)$ of the Securities Services Act.

62 See s $80(3)(e)$ of the Financial Markets Act which recycled the provisions of s 75(3)(e) of the Securities Services Act.

63 See s $80(3)(\mathrm{g})$ of the Financial Markets Act which merely resembles $\mathrm{s} 75(3)(\mathrm{g})$ of the Securities Services Act.

64 This is probably indirectly prohibited because there is no provision in the Financial Markets Act which expressly outlaws this type of trade-based market manipulation. On the other hand, the aforementioned type of trade-based market manipulation was expressly outlawed in $\mathrm{s} 75(3)(\mathrm{h})$ of the Securities Services Act.

65 This is not expressly prohibited in the Financial Markets Act but related deceptive conduct is discouraged in s 80(1)(a) read with subsection (3). However, the same conduct was expressly outlawed in s 75(3)(i) of the Securities Services Act.

66 See s $80(3)(f)$ of the Financial Markets Act which resembles s 75(3)(f) of the Securities Services Act.

67 Cassim "An Analysis of Market Manipulation under the Securities Services Act 36 of 2004 (Part 1)" 2008 SA Merc LJ 33 33-43.

68 See s 80 of the Financial Markets Act.

69 Ibid. 
based market manipulative practices are difficult to detect, investigate and prosecute. $^{70}$ Enforcement authorities around the world have surveillance systems and other measures in place to detect and combat market manipulation. ${ }^{71}$ Likewise, South Africa has mainly empowered the Financial Services Board and other bodies like the JSE to enforce the prohibition on market manipulation. For example, the JSE requires its members to comply with certain requirements to, inter alia, prevent all the forms of market manipulation by mandating them to give consideration to the circumstances of orders placed by clients before entering such orders in the JSE equitiestrading system and to be responsible for the integrity of such orders. ${ }^{22}$ The JSE's Surveillance Division operates a system that identifies unusual price and trading volumes and when possible market manipulation is detected, an initial investigation is carried out and the results are handed over to the Directorate of Market Abuse. Regardless of this, up until now, very little success has been achieved in respect of the settlements and prosecutions of cases involving trade-based market manipulation. ${ }^{73}$ Moreover, the Financial Markets Act still does not provide a civil remedy for trade-based market manipulation. Trade-based market manipulation is treated only as a criminal offence. This flaw was borrowed from the Securities Services Act ${ }^{74}$ and has remained unresolved in the Financial Markets Act. ${ }^{75}$

\section{Prohibition on insider trading}

\section{Criminal liability for insider trading}

As earlier stated ${ }^{76}$ insider trading is prohibited in the Financial Markets Act. ${ }^{77}$ Any person who violated the relevant provisions of the Financial Markets Act will be liable for a criminal offence of insider trading. ${ }^{78}$ For instance, actual dealing directly or indirectly or through an agent in securities listed on a regulated market by an insider who knew that he had inside information to which such securities relate or which are likely to be affected by it for his own personal benefit could give rise to a criminal offence of

70 Cassim 2008 SA Merc LJ 46-49; Barnes Stock Market Efficiency, Insider Dealing and Market Abuse (2009) 19-125.

71 Barnes Stock Market Efficiency, Insider Dealing and Market Abuse 19-125.

72 Rule 7.10 .1 of the JSE's Listing Requirements.

73 Statutory administrative sanctions have been successfully obtained in minimal cases of trade-based market manipulation such as iFour Properties Limited (R2 million penalty), SA Retail Properties Limited (2) (R2 million penalty), Stratcorp Limited (R10 000 penalty), New Rand Warrants Limited (R750 000 penalty), Imperial Holdings Limited (R25 000 penalty), King Consolidated Holdings Limited (R10 000 penalty), SilverBridge Holdings Limited (R10 000 penalty) and Sunflower December 2007 to January 2008 Contract (R50 000 penalty). This information was obtained from an interview that was conducted at the Financial Services Board by the author, with Mr Gerhard van Deventer (the Executive (2009

See $\mathrm{s} 75$.

75 See s 80 and other relevant provisions in Chapter X entitled "Market Abuse".

76 See paragraph 211 above.

77 S 78 and $\mathrm{s} 82$.

$78 \mathrm{~S} 78$ of the Financial Markets Act. 
insider trading. ${ }^{79}$ Nevertheless, it is not certain whether this prohibition applied to any unlawful transactions that related to other money-market instruments such as derivatives. This obscurity was also found in the Securities Services $\mathrm{Act}^{80}$ and is still addressed in the Financial Markets Act. ${ }^{81}$ The words "through an agent" were introduced in some insider-trading provisions under the Financial Markets Act. ${ }^{82}$ Therefore, any insider who knowingly and indirectly practised insider trading through an agent for his personal benefit will be expressly liable for a criminal offence. The extension of the criminal liability to dealing through an agent is a positive development, but it is not clear who exactly could be regarded as an agent for the purposes of this prohibition. ${ }^{83}$ This confusion could enable other persons who knowingly dealt in listed securities through agents as well as such agents to escape liability for their insider-trading offences. This flaw was recycled from the Securities Services $\mathrm{Act}^{84}$ and has remained unresolved under the Financial Markets Act. ${ }^{85}$

Actual dealing in securities for the benefit of another person is further prohibited. ${ }^{86}$ Therefore, any insider who knew that he had inside information and who dealt directly or indirectly for the benefit of any other person in any listed securities to which such inside information relates, or which were likely to be affected by it is liable for a criminal offence ${ }^{87}$ Notably, the presence of the words "through an agent" in this regard indicates that the inconsistencies found in some of the insider-trading provisions contained in the Securities Services $\mathrm{Act}^{88}$ are now addressed in the Financial Markets Act. ${ }^{89}$ It is hoped that this will, in the future, increase the convictions and prosecutions of criminal cases involving insider trading in South Africa.

An insider who knew that he had inside information and who encouraged or caused another person to deal, or discouraged or stopped another person from dealing in the securities listed on a regulated market to which the information relates, or which were likely to be affected by it is liable for a criminal offence. ${ }^{90}$ As earlier stated, ${ }^{91}$ the accused should have known that

$79 \mathrm{~S} 78(1)(\mathrm{a})$ of the Financial Markets Act. This status quo was imported from s 73(1)(a) of the Securities Services Act.

80 See $\mathrm{s} 73$.

81 See s 78 read with s 80 .

82 S 78(1)(a). This status quo was imported from s 73(1)(a) of the Securities Services Act.

$83 \mathrm{~S} 78(1)(a)$ of the Financial Markets Act. The same flaw was recycled from s 73(1)(a) of the Securities Services Act. Also see Cassim 2007 SA Merc LJ 67. The term "agent" is defined in other jurisdictions like Australia and the United Kingdom, see s 1042B of the Australian Corporations Act 50 of 2001(C'th); and s 62(1) and (2) of the English Criminal Justice Act 1993 (c 36).

$4 \quad S 73(1)(a)$

$S 78(1)(a)$

86 See s 78(2)(a) of the Financial Markets Act which resembles s 73(2)(a) of the Securities Services Act.

87 See s 78(2)(a) of the Financial Markets Act which resembles s 73(2)(a) of the Securities Services Act.

$38 \quad S 73(2)(a)$.

$89 \mathrm{~S} 78(2)(\mathrm{a})$ and (3)(a) of the Financial Markets Act.

90 See s 78(5) of the Financial Markets Act which merely resembles s 73(4) of the Securities Services Act.

91 Paragraph 211 above. 
he had inside information. It is possible for an accused to plead that he was ignorant of the price-sensitive nature of the inside information at the time when he encouraged or discouraged others to deal in the securities concerned. This status quo was borrowed from the Securities Services Act ${ }^{92}$ and has remained unchanged in the Financial Markets Act. ${ }^{93}$

An insider who knew that he had inside information and who disclosed such information to another person will be liable for a criminal offence. ${ }^{94}$ Nonetheless, improper disclosure of confidential inside information that relate to juristic persons by their agents who are not necessarily insiders appears not to be expressly covered under the Financial Markets Act. ${ }^{95}$ This flaw was recycled from the Securities Services Act ${ }^{96}$ and is still not resolved in the Financial Markets Act. ${ }^{97}$

\section{Civil liability for insider trading}

Any insider or person who is involved in insider-trading activities could incur civil liability. ${ }^{98}$ This civil liability could be imposed on an insider who knew that he had inside information and who dealt directly or indirectly or through an agent for his own account in securities listed on a regulated market to which the information related or which were likely to be affected by it and who made a profit or would have made a profit if he had sold the securities at any stage, or avoided a loss through such dealing unless he proved one of the defences outlined in the Financial Markets Act. ${ }^{99}$ Such a person is then liable at the suit of the Financial Services Board, in any court of competent jurisdiction or at the instance of the Enforcement Committee, for the administrative or civil compensatory fine as stipulated in the Financial Markets Act. ${ }^{100}$ Moreover, an insider who engaged in insider trading and made a profit or avoided a loss for personal benefit or for the benefit of any other person could incur civil liability. ${ }^{101}$ Therefore, the person involved is liable to pay the Financial Services Board an amount equivalent to the profit made or loss avoided or a penalty for compensatory and administrative purposes, ${ }^{102}$ but not exceeding three times the amount of the profit made or

S 73.

$S 78$.

94 See s 78(4)(a) of the Financial Markets Act which merely resembles s 73(3)(a) of the Securities Services Act.

95 See $\mathrm{3} 78(4)(\mathrm{a})$.

96 S 73(3)(a).

$S 78(4)(a)$.

$98 \mathrm{~S} 82$ of the Financial Markets Act.

99 See s 82 read with s 78. Similar conduct was also outlawed in s 77(1) of the Securities Services Act.

$100 \mathrm{~S}$ 82(1). A similar approach was also employed in S 77(1) of the Securities Services Act.

$101 \mathrm{~S} 82(1),(2)$ and (3) of the Financial Markets Act. A similar approach was also employed in $\mathrm{S}$ $77(1)(b)$ and (2)(b) of the Securities Services Act.

$102 \mathrm{~S} 82(1),(2),(3)$ and (6) of the Financial Markets Act. A similar approach was also employed in $s$ 77(1)(c), (2)(c), (3)(b), (4)(a) to (e) read with subsections (5) and (6) of the Securities Services Act but the words "compensatory and punitive purposes" are no longer employed in the Financial Markets Act, see s 82. 
loss avoided plus any other amount for interest and legal costs as determined by a competent court ${ }^{103}$ or the Enforcement Committee. ${ }^{104}$

The person or insider who indulged in insider-trading activities for the benefit of another person will be jointly and severally liable together with that other person to pay the Financial Services Board a penalty for compensatory and administrative purposes plus interest or costs as determined by the relevant courts and/or the Enforcement Committee. ${ }^{105}$ This joint and several liability is contingent upon a tippee's liability as an insider. Apparently, there is no liability for a party who deals in the securities in question for another person who is not an insider as defined in the Financial Markets Act. ${ }^{106}$ This shortcoming was borrowed from the Securities Services $\mathrm{Act}^{107}$ and is still not resolved in the Financial Markets Act. ${ }^{108}$ Civil liability is further imposed on an insider who knew that he had price-sensitive inside information and improperly disclosed such information to other persons. ${ }^{109}$ However, the Financial Markets Act did not expressly provide how companies could lawfully disclose price-sensitive inside information to relevant persons such as investment analysts so that they could not practise or fall victims to insider trading. ${ }^{110}$ This shortcoming was previously embedded in the Securities Services Act ${ }^{111}$ and has remained unresolved in the Financial Markets Act. ${ }^{112}$ Additionally, any person who knowingly encouraged or caused another person to deal in securities listed on a regulated market will incur civil liability. ${ }^{113}$ The discouragement of others from dealing in such securities by any person who knew that he had inside information is now expressly prohibited in the civil provisions of the Financial Markets Act. ${ }^{114}$ This was not the case under the Securities Services Act. ${ }^{115}$ Accordingly, it is hoped that the relevant provisions of the Financial Markets Act will be consistently enforced to ensure that no unscrupulous persons will evade their civil insider-trading liability.

103 These are usually High Courts and regional courts.

104 See $\mathrm{s} 82$ of the Financial Markets Act.

105 See s 82(3) of the Financial Markets Act which, to a great extent, recycled the provisions of s 77(5) of the Securities Services Act.

106 S 77 of the Financial Markets Act. See further Jooste 2006 SALJ 454-455.

107 S 72

108 S 82(3).

109 S 82(2) read with subsection (3) of the Financial Markets Act. Similar conduct was also prohibited in s 77(3) of the Securities Services Act.

110 See Jooste 2006 SALJ 452-453; and generally see Loubser (02-10-2006) 14-15 http://www.jse.co.za/public/insider/JSEbooklet.pdf (accessed 2013-10-06), for further related comments.

111 S 77(3).

112 S 82(2) and (3) read with s 78(4)

113 See s 82(2) read with subsection (3) of the Financial Markets Act, which largely resembles s 77(4) of the Securities Services Act.

114 S 82(2) read with subsection (3). Also see Jooste 2006 SALJ 455.

$115 \mathrm{Eg}$, see s 77(4) which left some room for unscrupulous persons who discouraged others from dealing in certain securities to evade their civil insider-trading liability. 


\section{Prohibition on "disclosure-based market manipulation"}

Publication of false or deceptive statements, promises and forecasts is prohibited under the Financial Markets Act. ${ }^{116}$ Consequently, any person who directly or indirectly made or published in respect of listed securities, or in respect of the past or future performance of a public company, any statement, promise or forecast which was, at the time and in the light of the circumstances in which it was made, false or misleading or deceptive in respect of any material fact and which the person knew, or ought reasonably to have known was false, misleading or deceptive will be guilty of an offence. ${ }^{117}$ Likewise, any person who directly or indirectly, made or published in respect of listed securities, or in respect of the past or future performance of a public company, any statement, promise or forecast which was, by reason of the omission of a material fact, rendered false, misleading or deceptive and which the person knew, or ought reasonably to have known was rendered false, misleading or deceptive by reason of the omission of that fact will be liable for an offence. ${ }^{118}$ This indicates that disclosure-based market manipulation was, and still is discouraged in South Africa. ${ }^{119}$ Thus, the issuing of false, deceptive or misleading statements reduces public investor confidence and can harm the integrity of the financial markets and is as such prohibited in South Africa. ${ }^{120}$ For example, incorrect published information regarding the financial state of a listed company may discourage or encourage investors to trade in the company's shares at prices that would not be sustainable when the true facts are later known. ${ }^{12}$

The making or publication of false statements regarding matters that are not directly associated with the company's current performance, but which may nevertheless artificially inflate the share prices is prohibited under the Financial Markets Act. ${ }^{122}$ For example, the publication or making of false claims regarding orders purchased or products developed by the company concerned will give rise to an offence under the Financial Markets Act. The prohibition on disclosure-based market manipulation also applies to matters relating to the non-publication of price-sensitive information or the omission of material facts, often done to conceal the negative effect it could have on the share prices. ${ }^{123}$ Nevertheless, no provision is made in the Financial Markets Act for any presumptions that provide insight as to when a fact or an omitted fact would be material for the purposes of disclosure-based market

$116 \mathrm{~S} 81$ of the Financial Markets Act which resembles s 76 of the Securities Services Act.

$117 \mathrm{~S} 81(1)(a)$ of the Financial Markets Act which resembles $s$ 76(1)(a) of the Securities Services Act.

118 S 81(1)(b) of the Financial Markets Act which resembles s 76(1)(b) of the Securities Services Act.

119 Cassim "An Analysis of Market Manipulation under the Securities Services Act 36 of 2004 (Part 2)" 2008 SA Merc LJ 177 177-178.

120 Loubser (02-10-2006) 24 http://www.jse.co.za/public/insider/JSEbooklet.pdf (accessed 2013-10-06); and Cassim 2008 SA Merc LJ 177-183.

121 Loubser (02-10-2006) 24 http://www.jse.co.za/public/insider/JSEbooklet.pdf (accessed 2013-10-06).

122 See s 81, which is largely similar to s 76 of the Securities Services Act. Also see Loubser (02-10-2006) 24 http://www.jse.co.za/public/insider/JSEbooklet.pdf (accessed 2013-10-06).

123 See $s$ 81(1)(b) of the Financial Markets Act which recycled the provisions of $s$ 76(1)(b) of the Financial Markets Act. Also see Cassim 2008 SA Merc LJ 180. 
manipulation. ${ }^{124}$ This flaw was directly imported from the Securities Services Act $^{125}$ and has remained unresolved in the Financial Markets Act. ${ }^{126}$ Further liability is imposed on persons who either intentionally or negligently published or made incorrect statements. ${ }^{127}$ For example, a company director who allowed a trading statement to be published without taking reasonable steps to ensure that such statement was correct will be liable for causing a false statement to be made or published negligently and recklessly. Nonetheless, the Financial Markets Act does not impose civil liability on disclosure-based market manipulation offenders. ${ }^{128}$ However, the JSE's Listing Requirements that prohibit false or misleading statements by the JSE's member companies are usually used to extend civil liability to such companies or other relevant entities and their agents. ${ }^{129}$ The aforesaid flaw was previously embedded in the Securities Services Act ${ }^{130}$ and is still not addressed in the Financial Markets Act. ${ }^{131}$ Moreover, disclosure-based market manipulation on the Internet is not expressly prohibited in the Financial Markets Act. ${ }^{132}$ This flaw was also borrowed from the Securities Services $\mathrm{Act}^{133}$ and has remained unresolved in the Financial Markets Act. ${ }^{134}$ Therefore, the Internet could be providing unscrupulous persons in South Africa with opportunities to participate in disclosure-based marketmanipulation activities more easily and faster ${ }^{135}$ Additionally, the words "directly or indirectly" ${ }^{\text {"136 }}$ which are employed ${ }^{137}$ do not seem to extend liability to secondary offenders who do not directly engage in disclosurebased market-manipulation practices but who simply aided and abetted others to commit such practices. This same flaw and obscurity was recycled from the Securities Services Act $^{138}$ and has remained unresolved in the Financial Markets Act. ${ }^{13}$

\section{Available penalties}

Criminal penalties can be imposed on all the three forms of market abuse which are outlawed in South Africa. ${ }^{140}$ Consequently, persons who engage in market-abuse activities could be sentenced to a fine not exceeding R50

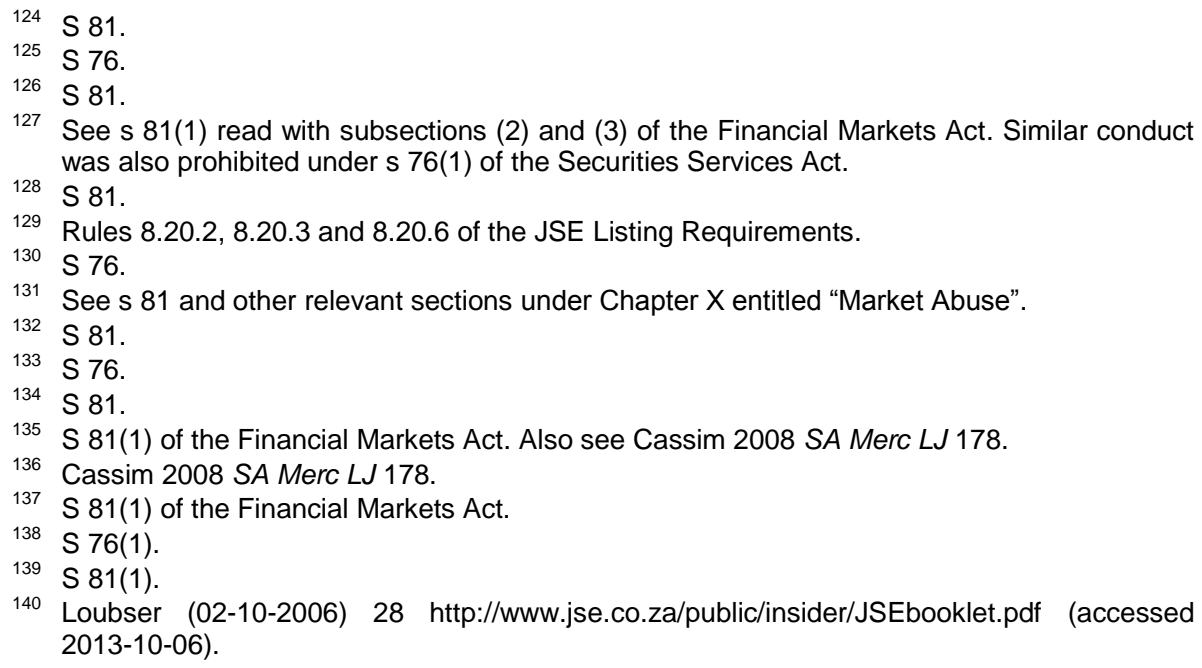


million or imprisonment for a period not exceeding ten years or both such fine and imprisonment. ${ }^{141}$ Notably, with regard to insider trading, the criminal sanctions were increased significantly from a fine of R2 million (previously stipulated in the Insider Trading Act) ${ }^{142}$ to R50 million under the Securities Services Act ${ }^{143}$ and recently, under the Financial Markets Act. ${ }^{144}$ While the introduction of relatively high market-abuse penalties is a positive improvement, it is submitted that standing alone, even the R50 million fine and a ten years' imprisonment term cannot be an effective deterrent. ${ }^{145}$ It is possible that prospects of enormous profits may outweigh the deterring effect of the stipulated fine and/or prison sentence. For example, companies may simply regard it as just another cost of doing business, especially where profits gained exceed the penalty imposed. ${ }^{146}$ Moreover, the fact that the actual perpetrators may plead guilty and be convicted of lesser offences may also have a negative effect on any impact a criminal sanction might have. Furthermore, the difficult burden of proof needed in the criminal prosecution of market-abuse offences has, to some extent, marred the prosecution of such offences in South Africa to date and this is unlikely to be different in future. ${ }^{147}$

Civil penalties for insider trading can be imposed on offenders for the profit made or loss avoided or as a penalty for compensatory and administrative purposes, an amount as determined by a competent court but not exceeding three times the amount of the profit made or loss avoided plus interest and legal costs as determined by the court or the Enforcement Committee. ${ }^{148}$ Nevertheless, prejudiced persons who proved their claims as provided for in the Financial Markets Act could only get their compensation after the Financial Services Board had recouped its expenses in relation to a successful litigation. ${ }^{149}$ This approach was also borrowed from the Securities Services Act. ${ }^{150}$ Nonetheless, it is submitted that, if not properly executed, this approach may give rise to bureaucracy and unnecessary delays before the affected persons receive their compensation.

141 See S 109(a) of the Financial Markets Act which resembles s 115(a) of the Securities Services Act.

$142 \mathrm{~S} 5$ of the Insider Trading Act.

$143 \mathrm{~S} 115(\mathrm{a})$.

144 S 109(a).

145 Cassim 2008 SA Merc LJ 194; and Jooste 2006 SALJ 453-454.

146 Ibid.

147 Only 32 cases of insider trading, 8 cases of trade-based market manipulation and no cases for disclosure-based market manipulation were reportedly investigated by the Financial Services Board during the period between January 1999 and December 2007. No convictions were obtained in all these criminal cases of market abuse. This information was obtained from an interview that was conducted at the Financial Services Board by the author, with Mr Gerhard van Deventer on 05 May 2009. Also see Jooste 2006 SALJ 453454.

148 S 82 of the Financial Markets Act. See paragraph 2222 above.

149 See s 82(4) read with subsections (5) and (6) of the Financial Markets Act. No civil penalties may, however, be levied against the culprits who indulge in market-manipulation practices. See further Whiting "Civil Liability for Insider Trading: A Comparison of the Insider Trading Act of 1998 with the Securities Services Act of 2004" 2005 Responsa Meridiana 99 116117.

150 See $\mathbf{5} 77$. 
Furthermore, administrative penalties are provided for all the three forms of market abuse that are prohibited by the Financial Markets Act. The Enforcement Committee may, on a referral basis, impose administrative penalties on persons who indulge in market-abuse activities. ${ }^{151}$ Therefore, administrative penalties, namely a civil monetary penalty, an order for remedial action, an administrative sanction, costs orders, separate order for legal costs, remuneration costs orders, a fine for compensatory purposes and other appropriate disciplinary sanctions can be imposed on the offenders. ${ }^{152}$ The Enforcement Committee can impose an administrative compensatory amount payable to the Financial Services Board for distribution to the victims only in respect of insider trading. ${ }^{153}$ No similar provision was made for market manipulation. This might be caused by the fact that it would be very difficult to accurately calculate the amount of loss incurred by the victims of market manipulation. ${ }^{154}$ Moreover, the Financial Markets Act does not provide any specific administrative functions of the Enforcement Committee in detail. ${ }^{155}$ Nonetheless, it is submitted that the introduction of additional and/or sufficient administrative penalties might have the effect of increasing the compliance with, and the enforcement of the market-abuse provisions in South Africa. ${ }^{156}$

\section{CONCLUDING REMARKS}

Numerous amendments to the market-abuse legislation were introduced from time to time in a bid to, inter alia, restore public-investor confidence and improve the regulation of market-abuse practices in South Africa. However, the Securities Services Act, like its predecessors, failed to expressly provide for other alternative enforcement methods like whistle-blowing, private rights of action and specialized insider trading courts to complement the Financial Services Board. Eventually and in a bid to, inter alia, enhance the enforcement of the market-abuse ban in South Africa, the Financial Markets Act was recently introduced and it retained most of the civil remedies, criminal penalties, administrative sanctions and regulatory bodies such as the Enforcement Committee, the Appeal Board and the Directorate of Market Abuse which were introduced by the Securities Services Act. ${ }^{157}$ Nonetheless, various gaps that were previously embedded in the Securities Services Act were reduplicated in the Financial Markets Act's relevant market-abuse provisions and it remains questionable whether such provisions are robust enough and/or going to be effectively implemented to prevent market abuse in the South African financial markets. Accordingly, it is submitted that the Financial Markets Act should be amended in order to provide appropriate presumptions that could be utilized by the relevant courts to obtain more

151 See s 82 of the Financial Markets Act.

152 Ibid. Also see Van Deventer "Harnassing Administrative Law in Encouraging Compliance" 2009 FSB Bulletin 3 3-4.

153 Cassim 2008 SA Merc LJ 195.

154 lbid.

155 See s 99 and other relevant sections under Chapter X entitled "Market Abuse" in the Financial Markets Act.

156 Van Deventer 2009 FSB Bulletin 3-4.

157 See sub-paragraphs under paragraphs 21 and 22 above. 
convictions in criminal cases of market abuse. Another option is to empower the relevant courts statutorily to streamline the standard of proof requirements, especially in criminal cases of market abuse in order to enable such courts to obtain more convictions. It is further suggested that the Financial Markets Act should be amended to enact a statutory provision for a definition of the concept of "market abuse" involving all the elements of this offence (how it is committed), many types of market abuse such as "attempted insider trading", "attempted market manipulation" and specific "tipping" offences in order to improve the enforcement of the market-abuse prohibition in South Africa.

It is also hoped, given the everlasting backlog in our criminal courts, that additional specialized market-abuse courts or tribunals and self-regulatory organs will be established in the future to complement the enforcement efforts of the Financial Services Board. Another option is to empower the Financial Services Board financially and statutorily to procure its own market-abuse surveillance systems and transfer the entire financial markets anti-market abuse-surveillance responsibility from the JSE to the Financial Services Board. With regard to penalties, it is recommended that the Financial Markets Act should be amended to enact specific provisions for separate and distinct maximum criminal penalties that can be imposed upon any juristic persons or individuals that commit or attempt to commit insidertrading or market-manipulation offences in South Africa, with much higher maximum criminal penalties being imposed on such juristic persons to increase deterrence and enhance the combating of market-abuse practices in the South African financial markets. It is also submitted that the Financial Markets Act should be reviewed to expressly provide civil penalties for market-manipulation offences. Likewise, it is submitted that the Financial Markets Act should be amended to expressly prohibit and/or provide penalties against any persons who commit Internet-related marketmanipulation offences in South Africa and elsewhere.

In a nutshell, the article has revealed that the various gaps that were previously embedded in the Securities Services Act's market-abuse ban were recycled and reduplicated in the Financial Markets Act's market-abuse provisions. Accordingly, it is hoped that the flaws exposed above will be addressed and the recommendations as enumerated in this article will be utilized by the relevant stakeholders in the future to enhance the combating of market-abuse activities in South Africa. 